\title{
Oral health-related quality of life in elderly and young patients with periodontal diseases
}

\author{
Özge Göktürk iD, ${ }^{1}$ Fatma Uçan Yarkaç (iD ${ }^{2 *}$ \\ ${ }^{1}$ Department of Periodontology, Faculty of Dentistry, \\ Bolu Abant Izzet Baysal University, Bolu, ${ }^{2}$ Department of \\ Periodontology, Faculty of Dentistry, Necmettin Erbakan \\ University, Konya, Turkey
}

\begin{abstract}
ObJective: Due to the increase in the prevalence of periodontal diseases, quality of life decreases with aging. The purpose of this study was to investigate the quality of life and periodontal disease in young adults and elderly individuals.
\end{abstract}

Materials and Method: A total of 104 individuals, including 52 elderly patients with periodontal disease (Test group; 37 with gingivitis and 15 with periodontitis) (mean age $67.56 \pm 3.12$ ) and 52 young adult patients with periodontal disease (Control group; 37 with gingivitis and 15 with periodontitis) (mean age $27.88 \pm 6.59$ ), were included in the study. The patients' quality of life was determined by the Oral Health Impact Profile-14 (OHIP-14) questionnaire. Clinical periodontal parameters (gingival index (GI), plaque index (PI), clinical attachment loss (CAL), and probing pocket depth (PPD)) were used in the evaluation.

RESULTS: In periodontitis, there was no difference in total OHIP scores between the groups $(p>0.05)$, whereas, in gingivitis, OHIP scores were higher in elderly patients $(p<0.05)$. While GI was significantly higher in elderly patients, PPD and CAL were significantly higher in young adult patients with periodontitis $(p<0.05)$. OHIP subgroups' scores for "physical pain, psychological discomfort, and psychological disability" were significantly higher in elderly patients $(p<0.05)$.

ConcLusion: Oral health-related quality of life was significantly lower in elderly patients with periodontal disease. While gingivitis had a significantly higher effect on the quality of life in elderly patients compared to younger patients, it was observed that there was no difference in both age groups in the presence of periodontitis. Improving oral health with atraumatic and effective treatment applications at early ages can prevent periodontal problems that may occur in advanced ages and increase the quality of life.

Received: August 5, 2020; Accepted: December 14, 2020

*Corresponding author: Dr. Fatma Uçan Yarkaç, Department of Periodontology,

Necmettin Erbakan University Faculty of Dentistry, Konya, 42050, Turkey

E-mail: fatma_ucan413@ hotmail.com
KEYWORDS: Adult; aged; gingivitis; periodontal diseases; quality of life

CitAtıon: Göktürk Ö, Uçan Yarkaç F. Oral health-related quality of life in elderly and young patients with periodontal diseases. Acta Odontol Turc 2021;38(2):28-34

EdıToR: Burcu Özdemir, Gazi University, Ankara, Turkey

Copyright: () 2021 Göktürk \& Uçan Yarkaç. This work is licensed under a Creative Commons Attribution License. Unrestricted use, distribution, and reproduction in any medium are permitted provided the original author and source are credited.

FunDING: None declared.

Conflict of INTEREST: The authors declare no conflict of interest related to this study.

\section{INTRODUCTION}

Periodontal disease, one of the most common chronic diseases, affects more than $65 \%$ of the population. ${ }^{1}$ Periodontitis, a form of periodontal disease, is characterized by severe destruction which may lead to edentulism early in life, ${ }^{2}$ resulting in aesthetic problems and functional constraints, as well as discomfort. ${ }^{3}$ Buset et al. ${ }^{4}$ reported that a correlation existed between the negative effect on the quality of life (QoL) and the severity of periodontal diseases. Durham et al..$^{5}$ found that the poor quality of life in periodontitis patients was related with psychological concerns, pain, halitosis, and aesthetics. These findings have been confirmed around the world..$^{6-8}$ Especially with regards to tooth loss, there is a potent evidence of its negative effect on the oral healthrelated quality of life (OHRQLL). ${ }^{9}$

In the evaluation of OHRQoL, the clinical findings and their expression as a social impact are combined. It measures the extent of the importance of health status in a normally functioning individual and how it can cause changes in behavior. ${ }^{10}$ This assessment of OHRQoL is presented as complement to previous subjective evidence found by clinicians. OHRQoL provides information on the quality of oral health status as well as its impact on the self-perceived need for dental and medical care. ${ }^{11}$

The elderly represent a specific category in the population because they require further dental care 
due to their special conditions and diseases. They may also experience certain limitations due to periodontal destruction in their teeth. ${ }^{12}$ Tooth loss due to poor oral health and periodontal diseases does not only affect phonetics, dietary intake, and nutritional status but also creates a risk for general health. Most of the studies representing the oral health of the elderly are limited to conventional measurements of oral diseases and give a limited understanding of how oral health affects the QoL. Measuring how dental or oral disorders affect the lives of individuals has the same importance of measuring its incidence and prevalence. ${ }^{12}$ Accordingly, the notion of OHRQoL is based on some questionnaires, including Geriatric Oral Health Assessment ${ }^{13}$ and Oral Health Impact Profile (OHIP) ${ }^{14}$ to evaluate the patient's self-perception. The most widely used evaluation tool is the OHIP-14, which measures the social effect caused by problems compromising oral health. ${ }^{15}$ The OHIP questionnaire recommends completing clinical measures with specific interest on problems related to the patient's physical and physiological needs. ${ }^{14,15}$ Considering the worldwide life expectancy and the increase in the elderly population, such measures need to be taken into account to ensure the QoL in the population over 60 years of age during the course of planning. ${ }^{16}$

Recently, it has been suggested that oral health surveillance in young people should include information on self-reported oral health, as in the general population, and this can help people better understand the importance of regular and thorough dental examinations. ${ }^{17,18}$ Self-reported oral health is one of the leading factors with an effect on the QoL and well-being. ${ }^{17,19}$ Kojima et al. $^{20}$ reported that management/prevention of temporomandibular disorders, stomatitis, and malocclusion might lead to better QoL in the young adult population. However, in previous studies, the negative effect of periodontal disease on OHRQoL has been examined less frequently compared to other oral problems, such as tooth loss and dental caries. Clinical symptoms of periodontal diseases are observed in the later stages; therefore, individuals may not be aware of the present periodontal diseases during the early stage. Individuals who are not aware that their periodontal condition can deteriorate may be late to apply for dental care. ${ }^{17}$ In order to prevent periodontal disease in young populations, signs and symptoms of periodontal diseases need to be recognized before a clinical examination. ${ }^{20}$ However, differences in the perception of OHRQoL by young adults or elderly individuals with periodontal diseases have been investigated in very few studies. ${ }^{17,18,20}$

A better understanding of the self-perception of people regarding the effect that periodontal disease has on the OHRQoL can help provide planning and therapy that fits the concerns and needs of the patient. To that end, the purpose of the present study was to investigate the effects of gingivitis and periodontitis on quality of life in young adults and elderly individuals.

\section{Materials ANd Method}

The study was approved by the Ethics Committee of Bolu Abant Izzet Baysal University Faculty of Medicine (2018/139) and was enforced in accordance with the relevant guidelines of the Declaration of Helsinki. All participants participated in the study signed the written informed consent.

\section{Study population}

A total of 108 patients, aged between 20 and 92, were included in the study. Four patients declined to participate in this study. The study was performed with 52 individuals for the elderly (test group) and 52 for the young adults (control group).

The inclusion criteria were: 1) the presence of at least 15 teeth, 2) to be diagnosed with gingivitis/periodontitis, and 3) being systemically healthy. Exclusion criteria were: 1) patients who were breastfeeding or pregnant, 2) patients with systemic diseases such as cardiovascular disease or diabetes, 3) patients requiring antibiotic prophylaxis, 4) patients who received periodontal therapy prior to 6 months, 5) patients using immune-inflammatory drugs, and 6) patients suffering from tooth pain due to deep caries, or had psychiatric disorders.

\section{Periodontal examination}

The behavioral and demographic data of each subject group were recorded, and then the radiographic and clinical evaluations were performed. The reliability of the measurements, made by the examiner (O.G.) who performed the periodontal examination, was analyzed with fifteen randomly selected patients who did not relate to the study by repeating periodontal measurements within 48 hours after initial evaluation. The kappa value between the visits for assessment of probing pocket depth (PPD) was 0.83 . The clinical examination included the evaluation of plaque index $(\mathrm{PI})$, gingival index (GI), ${ }^{21}$ PPD, and clinical attachment loss (CAL) at six sites around each tooth. Periodontal measurements were performed according to the nearest millimeter using manual periodontal probe.

The calibrated examiner determined the state of periodontal health and the diagnosis of a periodontal disease with respect to the criteria of Classification of Periodontal and Peri-Implant Diseases and Conditions of the 2017 World Workshop according to clinical and radiographic evaluation. ${ }^{22}$ Patients with no clinical attachment loss, no radiographic bone loss, having a probing pocket depth $<3 \mathrm{~mm}$ and bleeding on probing $\geq 10 \%$, were diagnosed with gingivitis. Patients who had a radiographic bone loss on the coronal third of tooth roots and interdental CAL, which was detectable at $\geq 2$ non-adjacent teeth or buccal or oral CAL $\geq 3$ $\mathrm{mm}$ with pocketing depth $\leq 5 \mathrm{~mm}$ detectable at $\geq 2$ teeth, were diagnosed with stage II periodontitis. 


\section{Evaluation of the quality of life}

The effect of periodontal disease on the quality of life was examined using the OHIP-14 questionnaire. ${ }^{14,15}$ OHIP-14 is a 14-item measurement and a self-reported oral health assessment index. OHIP-14 examines the quality of life in seven aspects: Functional Limitation (items 1 and 2), Physical Pain (items 3 and 4), Psychological Discomfort (items 5 and 6), Physical Disability (items 7 and 8), Psychological Disability (items 9 and 10), Social Disability (items 11 and 12), and Handicap (items 13 and 14). ${ }^{15}$ Ratings were made on a 5-point Likert scale; 4: very often/every day, 3: fairly often, 2: occasionally, 1: hardly ever, and 0 : never. All of the points given to 14 items were collected and the totals of OHIP-14 scores were calculated. The higher OHIP-14 scores indicate a poorer quality of life. OHIP-14 scale was previously validated by performing on Turkish dental outpatients. ${ }^{23}$ In addition, Balci et al. ${ }^{24}$ have reported that OHIP-14-TR is a reliable, valid, and comprehensible scale for measuring OHRQoL in the Turkish population.

\section{Statistical analysis}

All analyses were performed using a statistical package software program (SPSS, SPSS Inc., Armonk, NY, USA). Before the initiation of the study, a power analysis was performed. Individuals in each group were determined based on power calculation of $80 \%$ power with $5 \%$ type I error level. It was calculated based on an estimated $40 \%$ difference in oral health between young adults and elderly individuals with a ratio of $1: 1$ in periodontal diseases. ${ }^{25}$ The original number was 45 in each group, and 104 patients were included in the study to compensate for any possible drop-outs. Data were summarized as mean and standard deviation. Kolmogorov-Smirnov test was used to determine the normal distribution of data. The association between sociodemographic variables was tested with the Chi-square test. The comparisons of OHIP-14 scores between the groups were analyzed by independent groups t-test analysis. When comparing periodontal disease for the elderly and young adult individuals, the ANOVA analysis was used. The Cronbach alpha coefficient was calculated to determine internal consistency.
Table 1. Demographic data of the study population

\begin{tabular}{llll}
\hline & Control $(\mathbf{n}=\mathbf{5 2})$ & Test $(\mathbf{n}=\mathbf{5 2})$ & $\mathbf{p}^{*}$ \\
\hline $\begin{array}{l}\text { Periodontal status } \\
\text { [n (\%)] }\end{array}$ & & & \\
$\quad$ Gingivitis & $37(71.1)$ & $37(71.1)$ & \\
$\quad$ Periodontitis & $15(28.8)$ & $15(28.8)$ & \\
\hline $\begin{array}{l}\text { Education level } \\
\text { [n (\%)] }\end{array}$ & & & \\
$\quad$ Low & $11(21.2)$ & $34(65.4)$ & $\mathbf{0 . 0 0 0}$ \\
$\quad$ Moderate & $11(21.2)$ & $7(13.5)$ & \\
$\quad$ High & $30(57.7)$ & $11(21.2)$ & \\
\hline Income level & & & \\
[n (\%)] & & & \\
$\quad$ Low & $9(17.3)$ & $11(21.2)$ & 0.713 \\
$\quad$ Moderate & $23(44.2)$ & $19(36.5)$ & \\
$\quad$ High & $20(38.5)$ & $22(42.3)$ & \\
\hline Gender [n (\%)] & & & \\
$\quad$ Female & $34(65.4)$ & $18(59.6)$ & 0.686 \\
$\quad$ Male & $31(34.6)$ & $21(40.4)$ & \\
\hline Age (Mean \pm SD) & $28.44 \pm 6.67$ & $67.48 \pm 3.12$ & $\mathbf{0 . 0 0 0}$ \\
\hline
\end{tabular}

${ }^{*}$ Chi-square statistics. Statistically significant $p$ values $(p<0.05)$ are indicated with bold.

The statistically significant level of comparisons was determined as $p<0.05$.

\section{Results}

The demographic data are presented in Table 1. The mean ages of test and control groups were $67.56 \pm$ 3.12 and $27.88 \pm 6.59$, respectively $(p<0.05$, Table 1$)$.

Table 2 shows the periodontal parameters of patients diagnosed with periodontitis and gingivitis. When the clinical parameters in patients with gingivitis were evaluated, GI scores were found to be higher in the test group. In addition, PPD and CAL measurements were higher in the control group suffering from periodontitis $(p<0.05$, Table 2). No difference was found between the QoL scores of the periodontitis individuals ( $p>0.05$ ). The OHIP-14 scores were found to be higher in elderly

Table 2. Periodontal clinical parameters and quality of life scores in test and control groups (mean \pm standard deviation)

\begin{tabular}{lllllll}
\hline & \multicolumn{3}{l}{ Gingivitis } & \multicolumn{3}{l}{ Periodontitis } \\
\cline { 2 - 7 } & Control group & Test group & $\mathbf{p}^{*}$ & Control group & Test group & $\mathbf{p}^{*}$ \\
\hline PPD $(\mathbf{m m})$ & $2.39 \pm 0.39$ & $2.21 \pm 0.71$ & 0.927 & $5.09 \pm 0.36$ & $4.46 \pm 0.51$ & $\mathbf{0 . 0 1 1}$ \\
GI & $1.70 \pm 0.69$ & $2.75 \pm 0.59$ & $\mathbf{0 . 0 0 0}$ & $2.53 \pm 0.63$ & $2.33 \pm 0.48$ & 0.305 \\
$\mathrm{PI}$ & $2.13 \pm 0.71$ & $2.05 \pm 0.62$ & 0.760 & $2.62 \pm 0.49$ & $2.56 \pm 0.49$ & 0.744 \\
CAL & - & - & - & $3.28 \pm 0.04$ & $3.14 \pm 0.02$ & $\mathbf{0 . 0 1 0}$ \\
OHIP-14 (Total) & $8.72 \pm 10.56$ & $14.81 \pm 8.10$ & $\mathbf{0 . 0 0 7}$ & $10.06 \pm 10.25$ & $12.93 \pm 6.35$ & 0.365 \\
OHIP-Functional limitation & $1.32 \pm 2.04$ & $1.08 \pm 1.46$ & 0.557 & $1.33 \pm 1.29$ & $1.86 \pm 1.45$ & 0.298 \\
OHIP-Pain and discomfort & $1.78 \pm 2.08$ & $3.62 \pm 2.01$ & $\mathbf{0 . 0 0 0}$ & $1.53 \pm 1.99$ & $3.80 \pm 1.93$ & $\mathbf{0 . 0 0 4}$ \\
OHIP-Psychosocial impacts & $2.62 \pm 3.58$ & $6.72 \pm 4.49$ & $\mathbf{0 . 0 0 0}$ & $4.13 \pm 4.61$ & $3.60 \pm 3.01$ & 0.711 \\
\hline
\end{tabular}

*Independent samples t-test analysis. Statistically significant $p$ values ( $p<0.05)$ are indicated with bold. PI: plaque index; Gl: gingival index; PPD: probing pocket depth; CAL: clinical attachment loss; OHIP: Oral Health Impact Profile 
individuals with gingivitis, indicating that elderly individuals suffer more from "pain, physical and psychological discomfort" ( $p<0.05$, Table 2$)$.

The general distribution of the OHIP-14 items along with the scores of the test group is presented in Table 3. The effect of oral health on the QoL in elderly patients is statistically significant in terms of "physical pain, psychological disability, and psychological discomfort". Eighty-three percent of elderly patients reported a painful condition due to complications concerning the teeth and gums. In addition, $67 \%$ of elderly patients declared that they felt self-conscious due to their teeth and gums, and $69 \%$ of elderly patients stated that they had difficulties in relaxing because of their teeth and gums (Table 3).

The general distribution of the OHIP-14 items and the scores of the control group are presented in Table 3. The effect of oral health on the QoL of young adult

Table 3. Distribution of OHIP-14 individual item in test and control groups' responses. Data are represented as n (\%).

\begin{tabular}{|c|c|c|c|c|c|}
\hline & Never 0 & Seldom 1 & Sometimes 2 & Often 3 & Very Often 4 \\
\hline \multicolumn{6}{|l|}{ Test group } \\
\hline \multicolumn{6}{|l|}{ Functional limitation } \\
\hline 1. Trouble pronouncing words & $35(67.3)$ & 7 (13.5) & $9(17.3)$ & $1(1.9)$ & $0(0)$ \\
\hline 2. Sense of taste worse & $28(53.8)$ & $10(19.2)$ & $12(23.1)$ & $2(3.8)$ & $0(0)$ \\
\hline \multicolumn{6}{|l|}{ Physical pain } \\
\hline 3. Painful aching in mouth & $9(17.3)$ & $5(9.6)$ & $28(53.8)$ & $10(19.2)$ & $0(0)$ \\
\hline 4. Uncomfortable to eat foods & $10(19.2)$ & $10(19.2)$ & $11(21.2)$ & $16(30.8)$ & $5(9.6)$ \\
\hline \multicolumn{6}{|l|}{ Psychological discomfort } \\
\hline 5. Being self-conscious & $17(32.7)$ & $12(23.1)$ & $9(17.3)$ & $14(26.9)$ & $0(0)$ \\
\hline 6. Felt tense & $19(36.5)$ & $7(13.5)$ & $18(34.6)$ & $7(13.5)$ & $1(1.9)$ \\
\hline \multicolumn{6}{|l|}{ Physical disability } \\
\hline 7. Unsatisfactory diet & $30(57.7)$ & $13(25)$ & $9(17.3)$ & $0(0)$ & $0(0)$ \\
\hline 8. Had to interrupt meals & $26(50)$ & $11(21.2)$ & $11(21.2)$ & $4(7.7)$ & $0(0)$ \\
\hline \multicolumn{6}{|l|}{ Psychological disability } \\
\hline 9. Difficult to relax & $16(30.8)$ & $19(36.5)$ & $8(15.4)$ & $7(13.5)$ & $2(3.8)$ \\
\hline 10. Being embarrassed & $25(48.1)$ & $12(23.1)$ & $11(21.2)$ & $1(1.9)$ & $3(5.8)$ \\
\hline \multicolumn{6}{|l|}{ Social disability } \\
\hline 11. Being irritable with others & $35(67.3)$ & $5(9.6)$ & $12(23.1)$ & $0(0)$ & $0(0)$ \\
\hline 12. Difficulty doing usual jobs & $26(50)$ & $13(25)$ & $13(25)$ & $0(0)$ & $0(0)$ \\
\hline \multicolumn{6}{|l|}{ Handicap } \\
\hline 13. Felt life is less satisfying & $32(61.5)$ & $12(23.1)$ & $6(11.5)$ & $2(3.8)$ & $0(0)$ \\
\hline 14. Totally unable to function & $17(32.7)$ & $19(36.5)$ & $11(21.2)$ & $5(9.6)$ & $0(0)$ \\
\hline \multicolumn{6}{|l|}{ Control group } \\
\hline \multicolumn{6}{|l|}{ Functional limitation } \\
\hline 1. Trouble pronouncing words & $32(61.5)$ & $7(13.5)$ & $7(13.5)$ & $4(7.7)$ & $2(3.8)$ \\
\hline 2. Sense of taste worse & $39(75)$ & $4(7.7)$ & $6(11.5)$ & $0(0)$ & $3(5.8)$ \\
\hline \multicolumn{6}{|l|}{ Physical pain } \\
\hline 3. Painful aching in mouth & $32(61.5)$ & $3(5.8)$ & $12(23.1)$ & $2(3.8)$ & $3(5.8)$ \\
\hline 4. Uncomfortable to eat foods & $31(59.6)$ & $2(3.8)$ & $16(30.8)$ & $2(3.8)$ & $1(1.9)$ \\
\hline \multicolumn{6}{|l|}{ Psychological discomfort } \\
\hline 5. Being self-conscious & $41(78.8)$ & $6(11.5)$ & $3(5.8)$ & $1(1.9)$ & $1(1.9)$ \\
\hline 6. Felt tense & $40(76.9)$ & $2(3.8)$ & $4(7.7)$ & $1(1.9)$ & $5(9.6)$ \\
\hline \multicolumn{6}{|l|}{ Physical disability } \\
\hline 7. Unsatisfactory diet & $34(65.4)$ & $8(15.4)$ & $3(5.8)$ & $2(3.8)$ & $5(9.6)$ \\
\hline 8. Had to interrupt meals & $39(75)$ & $3(5.8)$ & $6(11.5)$ & $2(3.8)$ & $3(3.8)$ \\
\hline \multicolumn{6}{|l|}{ Psychological disability } \\
\hline 9. Difficult to relax & $36(69.2)$ & $4(7.7)$ & $8(15,4)$ & $1(1.9)$ & $3(5.8)$ \\
\hline 10. Being embarrassed & $34(65.4)$ & $9(17.3)$ & $4(7.7)$ & $2(3.8)$ & $3(5.8)$ \\
\hline \multicolumn{6}{|l|}{ Social disability } \\
\hline 11. Being irritable with others & $41(78.8)$ & $7(13.5)$ & $2(3.8)$ & $2(3.8)$ & $0(0)$ \\
\hline 12. Difficulty doing usual jobs & $37(71.2)$ & $5(9.6)$ & $7(13.5)$ & $0(0)$ & $3(5.8)$ \\
\hline \multicolumn{6}{|l|}{ Handicap } \\
\hline 13. Felt life is less satisfying & $31(59.6)$ & $10(19.2)$ & $8(15.4)$ & $1(1.9)$ & $2(3.8)$ \\
\hline 14. Totally unable to function & $31(59.6)$ & $7(13.5)$ & $11(21.2)$ & $1(1.9)$ & $2(3.8)$ \\
\hline
\end{tabular}


Table 4. OHIP-14 and subscales scores (mean \pm standard deviation) and internal consistency in test and control groups (Cronbach's alpha values)

\begin{tabular}{|c|c|c|c|c|c|}
\hline & \multirow[b]{2}{*}{ Test group } & \multirow[b]{2}{*}{ Control group } & \multirow[b]{2}{*}{$\mathbf{p}^{*}$} & \multicolumn{2}{|c|}{ Cronbach's alpha values } \\
\hline & & & & Test group & Control group \\
\hline OHIP-14 & $14.2 \pm 7.62$ & $9.11 \pm 10.40$ & 0.005 & 0.792 & 0.736 \\
\hline Functional limitation & $1.30 \pm 1.48$ & $1.32 \pm 1.84$ & 0.953 & 0.780 & 0.752 \\
\hline Physical pain & $3.67 \pm 1.97$ & $1.71 \pm 2.04$ & 0.000 & 0.757 & 0.688 \\
\hline Psychological discomfort & $2.69 \pm 2.15$ & $1.00 \pm 1.93$ & 0.000 & 0.761 & 0.694 \\
\hline Physical disability & $1.46 \pm 1.56$ & $1.32 \pm 2.16$ & 0.717 & 0.744 & 0.720 \\
\hline Psychological disability & $2.17 \pm 2.13$ & $1.34 \pm 1.87$ & 0.038 & 0.759 & 0.676 \\
\hline Social disability & $1.30 \pm 1.51$ & $0.92 \pm 1.63$ & 0.216 & 0.769 & 0.713 \\
\hline Handicap & $1.30 \pm 1.51$ & $1.48 \pm 1.60$ & 0.573 & 0.773 & 0.713 \\
\hline
\end{tabular}

*Independent samples t-test analysis. Statistically significant $p$ values $(p<0.05)$ are indicated with bold. OHIP: Oral Health Impact Profile

patients was statistically significant in terms of "physical pain, psychological disability, and psychological discomfort". Thirty-nine percent of young adult patients reported experiencing discomfort while eating due to problems with their teeth and gums. Approximately $21 \%$ of young adult patients stated that they felt selfconscious and $30 \%$ of young adult patients felt tense because of problems with their teeth and gums (Table $3)$.

The internal consistency coefficients of the individual subscales and OHIP-14 scores of all groups are shown in Table 4. Cronbach's alpha values in elderly patients were 0.792 and ranged from 0.744 to 0.780 . Cronbach's alpha values in young adult patients were 0.736 and ranged from 0.676 to 0.752 for OHIP-14 subscales (Table 4).

The total scores obtained from OHIP-14 and subscales of the control and test groups are presented in Table 4. OHIP-14 scores and "Physical pain, psychological disability, and psychological discomfort" subscales showed a statistically significant difference between control and test groups $(p<0.05$, Table 4$)$.

\section{Discussion}

The purpose of this study was to evaluate the oral health-related quality of life and periodontal disease in younger adults and elderly individuals. The findings provided by this study showed that there was a statistically significant difference between young adults and elderly patients in terms of OHIP-14 score and its subscales as "Physical pain, psychological disability, and psychological discomfort". Additionally, elderly individuals had higher OHIP-14 scores and poorer QoL.

It has been shown that as age progresses, certain conditions, such as loss of income, the presence of chronic disease, and exclusion from health programs, affect health and QoL. ${ }^{26,27}$ Lamster et al. ${ }^{28}$ demonstrated that periodontal health was important for elderly people by indicating a relation between periodontitis and root caries, which was not present in young adults. Liang et al. ${ }^{29}$ found that elderly patients who had a poor chewing ability, removable denture-wearing, and a periodontal disease had a lower quality of life. Another study also reported that the number of missing teeth, gender, mean probing depth, and mean clinical attachment loss frequently affected OHRQoL, and age was negatively associated with lower OHRQoL. ${ }^{30}$ However, the effect of oral health on QoL in the young population was evaluated in a few studies. Yamane-Takeuchi et al. ${ }^{31}$ investigated the relationship between QoL and clinical oral health along with subjective oral symptoms such as temporomandibular disease, stomatitis, and oral pain in young individuals. They found that self-rated oral health, malocclusion, oral pain, and the decayed, missed, filled teeth scores were directly related with the OHRQoL, and subjective symptoms of recurrent aphthous stomatitis and temporomandibular disorders were both indirectly and directly associated. ${ }^{31}$ Besides, they concluded that the mean score $( \pm S D)$ of OHIP-14 was $1.92 \pm 5.47$ and this score was relatively low compared to those in elderly people and clinical periodontal conditions such as the plaque score, and \% bleeding on probing did not show a significant effect on OHRQoL. ${ }^{31}$ Ustaoglu et al. ${ }^{32}$ evaluated the effect of generalized aggressive periodontitis (GAP), generalized chronic periodontitis (GCP), and gingivitis (G) on QoL in young adult individuals. They concluded that different forms of periodontal disease had different effects on the QoL of patients, and patients with GCP and GAP had poorer QoL than $\mathrm{G}$ patients. In the present study, young adult patients had low OHIP-14 scores compared to elderly patients. There were no differences between young and elderly patients with periodontitis in terms of OHIP-14 scores, functional limitation, and psychosocial effects. These findings show that periodontitis has a similar effect on the QoL among the young and the elderly. Elderly patients with periodontitis had lower QoL in terms of discomfort compared to the young adult patients, and this result was consistent with other studies. ${ }^{8,32,33} \mathrm{Be}$ sides, the increase in the number of tooth loss in the elderly compared to young people in periodontitis may be the reason why elderly periodontitis patients have lower QoL in terms of discomfort. OHIP scores were lower in elderly patients with gingivitis compared to young patients with gingivitis. These results show that gingivitis affects the QoL of elderly patients more than young people. Early diagnosis and early therapy of oral 
diseases should be considered in the improvement of OHRQoL in young adults as in the elderly.

Previous studies evaluating the QoL showed that there was an association between OHRQoL and the clinical status of periodontitis patients with periodontal symptoms. 4,34,35 Periodontal diseases affect the QoL negatively by causing pain and physical, psychological, and social disability, functional limitation. ${ }^{4,28,36} \mathrm{Ng}$ and Leung investigated the association between QoL and periodontal status and reported that a comparison of the mean OHIP-14S scores of the healthy/groups with low levels of periodontal clinical attachment loss and the groups with high/severe loss of periodontal clinical attachment demonstrated statistically significant differences with respect to the subscales of functional limitation, psychological discomfort, physical pain, psychological, and physical disabilities. ${ }^{8}$ Grover et al. ${ }^{6}$ found that the most influenced domain in the rural population was "functional limitation", whereas "psychological disability" was the most influenced in the urban population and statistically positive correlation was revealed between the OHIP-14 and periodontal parameters. In this study, the effect of oral health on the QoL in young adults and elderly people with gingivitis was found statistically significant in both groups in terms of "physical pain, psychological discomfort, and psychological disability". According to the previous study's findings, two psychological parameters may be related to the symptoms of gingivitis such as the change of color, bleeding, redness, and edema. Tomazoni et al. ${ }^{36}$ reported that the prevalence of gingivitis was associated with negative perceptions of daily life in adolescents. Ediani Machado et al. showed that the presence of gingival bleeding caused a decrease in the QoL. ${ }^{37}$ Similarly, in the present study, the quality of life of elderly patients with gingivitis was found to be lower in which the gingival index was significantly higher than the young adult patients.

Another factor affecting the QoL is the education level. Studies reported a negative correlation between periodontal diseases and the level of education. The individuals suffering from a periodontal disease with a high severity were reported to have a lower education level. ${ }^{38}$ Recently, He et al. ${ }^{39}$ has demonstrated that periodontitis has a direct dose-response relationship with OHRQoL regardless of sociodemographic factors and variability in determinants, such as gender, age, education, and tooth decay variance. Similarly, it was reported by another study that sociodemographic factors such as gender, age, and income level affect oral health. ${ }^{40}$ The individual's level of education may be a factor affecting OHRQoL. In this study, elderly people had a significantly lower education level in comparison to young adults. Consequently, poor QoL in elderly people may be related to lower education level.

Based on this study and literature data, it can be stated that the quality of life decreases with aging; conjointly, the clinical symptoms of inflammation in peri- odontal tissues affect the QoL in a negative manner.

This study has some limitations. A major limitation of this study is the small sample size. The effect of periodontal status on quality of life should be evaluated with more participants. Another limitation of this study includes the lack of additional data on other specific dental problems such as food impaction, caries, gingival recessions, and other dental problems.

\section{Conclusion}

In this study, it was observed that the QoL was lower in elderly individuals with periodontal disease compared to young adults. In addition, the effect of gingivitis on the QoL was higher compared to periodontitis in both young adults and elderly individuals. Information obtained from this study can help determine to what extent periodontal treatments will improve the quality of life. However, additional studies are still needed to examine the relationship between age-related QoL and periodontal status.

\section{References}

1. Dye BA. Global periodontal disease epidemiology. Periodontol 2000 2012;58:10-25.

2. Guerrero A, Griffiths GS, Nibali L, Suvan J, Moles DR, Laurell L, et al. Adjunctive benefits of systemic amoxicillin and metronidazole in nonsurgical treatment of generalized aggressive periodontitis: a randomized placebo-controlled clinical trial. J Clin Periodontol 2005;32:1096107.

3. Albandar JM, Tinoco EM. Global epidemiology of periodontal diseases in children and young persons. Periodontol 2000 2002;29:153-76.

4. Buset SL, Walter C, Friedmann A, Weiger R, Borgnakke WS, Zitzmann NU. Are periodontal diseases really silent? A systematic review of their effect on quality of life. J Clin Periodontol 2016;43:333-44.

5. Durham J, Fraser HM, McCracken GI, Stone KM, John MT, Preshaw PM. Impact of periodontitis on oral health-related quality of life. J Dent 2013;41:370-6.

6. Grover V, Malhotra R, Dhawan S, Kaur G. Comparative Assessment of Oral Health Related Quality of Life in Chronic Periodontitis Patients of Rural and Urban Populations in Punjab. Oral Health Prev Dent 2016;14:235-40.

7. Eltas A, Uslu MO, Eltas SD. Association of Oral Health-related Quality of Life with Periodontal Status and Treatment Needs. Oral Health Prev Dent 2016;14:339-47.

8. Ng SK, Leung WK. Oral health-related quality of life and periodontal status. Community Dent Oral Epidemiol 2006;34:114-22.

9. Gerritsen AE, Allen PF, Witter DJ, Bronkhorst EM, Creugers NH. Tooth loss and oral health-related quality of life: a systematic review and meta-analysis. Health Qual Life Outcomes 2010;8:126.

10. Locker D. Measuring oral health: a conceptual framework. Community Dent Health 1988;5:3-18.

11. Sánchez-García S, Heredia-Ponce E, Juárez-Cedillo T, GallegosCarrillo K, Espinel-Bermúdez C, de la Fuente-Hernández J, et al. Psychometric properties of the General Oral Health Assessment Index (GOHAI) and dental status of an elderly Mexican population. J Public Health Dent 2010;70:300-7.

12. Murariu A. Oral health and quality of life in the adult population. 2nd ed. Romania: Junimea Publishing House; 2008.

13. Atchison KA, Dolan TA. Development of the Geriatric Oral Health Assessment Index. J Dent Educ 1990;54:680-7.

14. Slade GD, Spencer AJ. Development and evaluation of the Oral 
Health Impact Profile. Community Dent Health 1994;11:3-11.

15. Slade GD. Derivation and validation of a short-form oral health impact profile. Community Dent Oral Epidemiol 1997;25:284-90.

16. Rekhi A, Marya CM, Oberoi SS, Nagpal R, Dhingra C, Kataria S Periodontal status and oral health-related quality of life in elderly residents of aged care homes in Delhi. Geriatr Gerontol Int 2016;16:47480 .

17. Ueno M, Zaitsu T, Ohara S, Wright C, Kawaguchi Y. Factors influencing perceived oral health of Japanese middle-aged adults. Asia Pac J Public Health 2015;27:NP2296-304.

18. Ostberg AL, Eriksson B, Lindblad U, Halling A. Epidemiological dental indices and self-perceived oral health in adolescents: ecological aspects. Acta Odontol Scand 2003;61:19-24.

19. Hoq MI, Niyonsaba F, Ushio H, Aung G, Okumura K, Ogawa H. Human catestatin enhances migration and proliferation of normal human epidermal keratinocytes. J Dermatol Sci 2011;64:108-18.

20. Kojima A, Ekuni D, Mizutani S, Furuta M, Irie K, Azuma T, et al. Relationships between self-rated oral health, subjective symptoms, ora health behavior and clinical conditions in Japanese university students: a cross-sectional survey at Okayama University. BMC Oral Health 2013;13:62

21. Löe $H$. The Gingival index, the Plaque index and the Retention Index Systems. J Periodontol 1967;38:610-6.

22. Caton JG, Armitage G, Berglundh T, Chapple ILC, Jepsen S, Kornman $\mathrm{KS}$, et al. A new classification scheme for periodontal and periimplant diseases and conditions-Introduction and key changes from the 1999 classification. J Periodontol 2018;89 suppl 1:S1-8.

23. Mumcu G, Inanc N, Ergun $T$, Ikiz K, Gunes M, Islek U, et al. Oral health related quality of life is affected by disease activity in Behçet's disease. Oral Dis 2006;12:145-51.

24. Balci N, Alkan N, Gurgan CA. Psychometric properties of a Turkish version of the oral health impact profile-14. Niger J Clin Pract 2017;20:19-24.

25. Machin D, Campbell MJ, Tan SB, Tan SH. Sample size tables for clinical, laboratory and epidemiology studies. 4th ed. West Sussex: Wiley-Blackwell; 2009.

26. Sheiham A, Steele JG, Marcenes W, Tsakos G, Finch S, Walls AW Prevalence of impacts of dental and oral disorders and their effects on eating among older people; a national survey in Great Britain. Community Dent Oral Epidemiol 2001;29:195-203.

27. Wiggins RD, Higgs PF, Hyde M, Blane DB. Quality of life in the third age: key predictors of the CASP-19 measure. Ageing \& Society 2004;24:693-708.

28. Lamster IB, Asadourian L, Del Carmen T, Friedman PK. The aging mouth: differentiating normal aging from disease. Periodontol 2000 2016;72:96-107.

29. Liang YH, Chou C, Chen YJ, Chou YF, Lin CY, Chou C, et al. Impact of periodontal disease and chewing ability on the quality of life of the elderly in an affluent community. J Formos Med Assoc 2020;119:1693-701.

30. Botelho J, Machado V, Proença L, Oliveira MJ, Cavacas MA, Amaro $L$, et al. Perceived xerostomia, stress and periodontal status impact on elderly oral health-related quality of life: findings from a cross-sectional survey. BMC Oral Health 2020;20:199.

31. Yamane-Takeuchi M, Ekuni D, Mizutani S, Kataoka K, TaniguchiTabata A, et al. Associations among oral health-related quality of life, subjective symptoms, clinical status, and self-rated oral health in Japanese university students: a cross-sectional study. BMC Oral Health 2016;16:127.

32. Ustaoğlu G, Göller Bulut D, Gümüş KÇ, Ankarali H. Evaluation of the effects of different forms of periodontal diseases on quality of life with OHIP-14 and SF-36 questionnaires: A cross-sectional study. Int J Dent Hyg 2019;17:343-9.

33. Al-Harthi LS, Cullinan MP, Leichter JW, Thomson WM. The impact of periodontitis on oral health-related quality of life: A review of the evidence from observational studies. Aust Dent J 2013;58:274-7.

34. Eltas A, Uslu MÖ. Evaluation of oral health-related quality-of-life in patients with generalized aggressive periodontitis. Acta Odontol Scand 2013;71:547-52.

35. Bernabé E, Marcenes W. Periodontal disease and quality of life in British adults. J Clin Periodontol 2010;37:968-72.

36. Tomazoni F, Zanatta FB, Tuchtenhagen S, da Rosa GN, Del Fabro JP, Ardenghi TM. Association of gingivitis with child oral health-related quality of life. J Periodontol 2014;85:1557-65.

37. Ediani Machado M, Tomazoni F, Ruffo Ortiz F, Ardenghi TM, Zanatta FB. Impact of Partial-Mouth Periodontal Examination Protocols on the Association Between Gingival Bleeding and Oral Health-Related Quality of Life in Adolescents. J Periodontol 2017;88:693-701.

38. Gundala R, Chava VK. Effect of lifestyle, education and socioeconomic status on periodontal health. Contemp Clin Dent 2010;1:23-6.

39. He S, Wei S, Wang J, Ji P. Chronic periodontitis and oral healthrelated quality of life in Chinese adults: A population-based, cross-sectional study. J Periodontol 2018;89:275-84

40. da Silva Araújo AC, Gusmão ES, Batista JEM, Cimões R. Impact of periodontal disease on quality of life. Quintessence Int 2010;41:111-8.

\section{Periodontal hastalığı bulunun yaşlı ve genç hastalarda ağız sağığı ile ilgili yaşam kalitesi}

\section{ÖZET}

AmAÇ: Yaşlanma ile periodontal hastalıkların prevalansındaki artış yaşam kalitesini düşürmektedir. Bu çalışmanın amacı, genç erişkinlerde ve yaşlı bireylerde yaşam kalitesini ve periodontal hastalık durumunu değerlendirmektir.

GeREÇ Ve YönteM: Periodontal hastalığı olan 52 yaşlı birey (Test grubu: 37 gingivitisli ve 15 periodontitisli birey) (ortalama yaş $67.56 \pm 3.12$ ) ve periodontal hastalığı olan 52 genç birey (Kontrol grubu; 37 gingivitisli ve 15 periodontitisli birey) (ortalama yaş $27.88 \pm 6.59$ ) olmak üzere, toplam 104 birey çalışmaya dahil edildi. Hastaların yaşam kalitesi Ağız Sağlığı Etki Profili-14 (OHIP-14) anketi ile belirlendi. Periodontal durumu belirlemek için periodontal klinik parametreler (gingival indeks (Gi), plak indeksi (PI), sondalanabilir cep derinliği (SCD) ve klinik atașman seviyesi (KAS)) kullanıldı.

BULGULAR: Periodontitisli bireylerde, gruplar arasında toplam OHIP skorları arasında anlamlı farklılık görülmezken ( $p>0.05$ ), gingivitisli bireylerde OHIP skorlarının yaşı bireylere kıyasla daha yüksek olduğu gözlendi $(p<0.05)$. Periodontitisli bireylerde, genç hastalarda SCD ve KAS, yaşlı hastalarda ise Gi skorları daha yüksek bulundu $(p<0.05)$. OHIP alt grupları incelendiğinde, yaşlı bireylerde "fiziksel ağrı, psikolojik rahatsızlık ve psikolojik yetersizlik" skorlarının daha yüksek olduğu görüldü $(p<0.05)$.

Sonuç: Periodontal hastalığı olan yaşlı hastalar daha düşük ağız sağlığıyla ilişkili yaşam kalitesine sahipti. Gingivitisin yaş।ı hastalarda genç hastalara kıyasla yaşam kalitesi üzerine anlamlı derecede yüksek etkisi görülürken, periodontitis varlığında her iki yaș grubunda bir farkın olmadığı gözlenmiştir. Ağız sağlığını atravmatik ve etkili tedavi uygulamalarıyla erken yaşta geliştirmek, ileri yaşlarda ortaya çıkabilecek periodontal sorunları önleyebilir ve bireylerin yaşam kalitesini artırabilir.

AnAHTAR Kelimeler: Erişkin; gingivitis; periodontal hastalıklar; yaşam kalitesi; yaşı 